\title{
Efektifitas Edmodo Terhadap Hasil Belajar Mahasiswa PGSD Universitas Nusa Cendana
}

\author{
Fembriani*1, Taty R Koroh ${ }^{2}$, Pasmiyati ${ }^{3}$, Ribka Polin ${ }^{4}$ \\ ${ }^{1,2,3}$ Pendidikan Guru Sekolah Dasar, Fakultas Keguruan dan Ilmu Pendidikan, Universitas Nusa \\ Cendana, Indonesia \\ e-mail: Fembriani@staf.undana.ac.id
}

\begin{abstract}
ABSTRAK
Keterbatasan pertemuan dosen dan mahasiswa menjadi masalah penting di era ini. Dosen tidak dapat bertemu dengan mahasiswa, hal ini terjadi karena perkembangan virus COVID-19 yang menjadi ancaman. Akan tetapi kegiatan perkuliahan harus tetap dilaksanakan. Pembelajaran menggunakan edmodo menjadi salah satu jalan keluarnya. Matakuliah belajar pembelajaran dilaksanakan dengan menggunakan aplikasi edmodo. Matakuliah ini merupakan matakuliah dasar yang harus dikuasai mahasiswa PGSD. Sebagai calon guru mahasiswa harus menguasai teori-teori belajar yang ada dalam matakuliah belajar pembelajaran. embelajaran dengan edmodo mendapatkan hasil penelitian yang efektif. Hasil tersebut didapatkan dari analisis data yang telah dilakukan oleh peneliti. Analisis data dimulai dari uji validitas dan reliabilitas, dan mendapatkan hasil bahwa semua soal yang digunakan untuk penelitian dinyatakan valid dan reliabel. Hasil penelitian yang efektif dianalisis menggunakan uji T dan uji $N$-Gain. Uji $T$ mendapatkan hasil 0,000<0,005 hal ini berarti Ha diterima yaitu ada perbedaan nilai pretest dan posttest setelah mendapatkan pembelajaran dengan edmodo. Uji N-Gain mendapatkan hasil rata-rata 0,491 berada pada kategori sedang. Dapat disimpulkan pembelajaran dengan edmodo dapat meningkatkan hasil pembelajaran dengan kategori sedang.
\end{abstract}

Kata kunci : efektivitas, edmodo, hasil belajar

\begin{abstract}
The limitations of lecturer and student meetings are an important issue in this era. Lecturers does not meet with students, this is due to the development of the COVID-19 virus which is a threat. However, learning activities must still be carried out. Learning with edmodo is one way out. Learning subjects using the Edmodo application. Basic course that must be mastered by PGSD students. As prospective teachers, students must master theories of learning that exist in learning. Learning with edmodo gets effective research results. These results are obtained from data analysis. Data analysis starts from the validity and reliability test, and the results that all the questions used for research are valid and reliable. Effectiveness research results were analyzed using the T test and $N$-Gain test. $T$ test results obtained 0,000 <0.005, this means that Ha is accepted, namely there is a difference in the value of the pretest and posttest after getting learning with Edmodo. The N-Gain test found an average of 0.491 in the medium category. It can be concluded that learning with edmodo can improve learning outcomes in the medium category.
\end{abstract}

Keywords: effectiveness, edmodo, learning outcomes

\section{PENDAHULUAN}

Pandemi virus Corona 2019 (COVID 19) telah membuat perubahan di dunia demikian juga di Indonesia. Berbagai sektor kegiatan telah berubah karena virus ini. Pada sektor pendidikan juga terjadi perubahan yang besar. Pendidikan khususnya di perguruan tinggi yang biasa dilaksanakan dengan proses tatap muka dosen dan mahasiswa sekarang harus menggunakan pembelajaran jarak jauh. Hal ini terjadi karena tidak memungkinkan dosen dan mahasiswa bertemu terkait virus ini. Sebisa mungkin dosen harus mencari alternatif pembelajaran jarak jauh agar pendidikan tetap berjalan. Di era informasi globalisasi informasi seperti saat ini terdapat beberapa trend di bidang telekomunikasi yaitu sudah saatnya diaplikasikan dalam proses pembelajaran. Ilmu pengetahuan semakin berkembang dari masa ke masa, perkembangan ilmu pengetahuan ini mendukung untuk terciptanya teknologi-teknologi baru yang menandai adanya kemajuan zaman, hingga kini teknologi yang berkembang sudah memasuki tahap digital, 
Jurnal Ilmiah KONTEKSTUAL, Volume.2, No.01, Agustus 2020, pp. 8-14

termasuk di Indonesia, setiap bidang sudah mulai memanfaatkan teknologi untuk memudahkan pekerjaan, termasuk juga di bidang pendidikan [1]. Lebih lanjut penggunaan media pembelajaran di era revolusi industry 4.0 dituntut untuk berorientasi pada IT, sehingga penggunaan media yang tepat sangat mempengaruhi pencapaian pembelajaran [2].

Pemanfaatan teknologi informasi dalam sistem pembelajaran khususnya pada pembelajaran jarak jauh dimaksudkan agar meningkatkan kemandiria, individualisasi dan otonomi peserta belajar didalam proses pembelajarannya sesuai dengan karakteristik dari pembelajaran jarak jauh itu sendiri. Kondisi yang ada selama ini bahwa sisem pembelajaran yang ada dalam pendidikan jarak jauh belum fleksibel dan masih berupa refleksi dari pembelajaran yang centralized. seiring dengan pesatnya teknologi informasi, sistem pembelajaran jarak jauh sebenarnya dapat berupa menjadi sebuah sistemm yang interaktif, dapat melibatkan kelompokkelompok tanpa mengurangi keindividuan masing-masing peserta didik, dilain pihak dapat pula bersifat sangat private dimana peserta didik dapat dikonttrol disegala situasi tanpa dibatasi oleh waktu dan ruang.

Persoalan pendidikan bukanlah lagi masalah yang harus diselesaikan oleh satu pihak saja namun harus menjadi pola pikir banyak pihak, tetapi bukan berarti semua pihak juga ikut memutuskan masalah pendidikan ini. Banyak hal yang harus diselesaikan dalam pendidikan itu sendiri, terutama tuntutan atas peran strategis pendidikan sebagai suatu pranata sosial yang kuat dan berwibawa untuk mewujudkan pencerdasan kehidupan bangsa, telah mendorong tumbuhnya berbagai inovasi dalam sistem pendidikan. Pendidikan harus selalu mengikuti perkembangan zaman agar mampu mencetak peserta didik yang peka terhadap perkembangan. Salah satu bentuk perkembangan dalam dunia pendidikan yaitu berkenaan dengan media pembelajaran [3]. Media pembelajaran yang digunakan dapat mendukung kegiatan belajar yang dilakukan. Hal ini karena belajar merupakan aktivitas individu dalam memperoleh pengetahuan, perilaku, dan keterampilan dengan cara mengolah materi pembelajaran [4]. Penggunaan media yang tepat dalam proses pembelajaran tentu akan memperpudah pencapaian tujuan pembelajaran.

Usaha pembangunan pendidikan dengan cara-cara yang konvensional seperti membangun gedung-gedung sekolah dan mengangkat guru baru, hal ini tidak lagi dapat dipandang sebagai langkah yang mampu memecahkan masalah pendidikan. Pembaharuan pendidikan tidak mungkin lagi dapat dilakukan dengan cara-cara yang lama dengan menggunakan metode yang lama. Seiring dengan perkembangan di banyak bidang yang cenderung tidak menentu, tuntutan akan peningkatan kualitas sumber daya manusia semakin muncul kepermukaan. Kedudukan strategis, baik disektor umum maupun swasta, menuntut sumber daya manusia yang memiliki latar belakang pendidikan yang lebih tinggi. Sehingga wajar jika motivasi publik untuk terus menambah pengetahuannya melalui institusi pendidikan tinggi semakin meningkat. Seorang dosen dalam usahanya melaksanakan pembangunan pendidikan dapat menerapkan konsep pembelajaran jarak jauh salah satunya dengan menggunakan aplikasi edmodo. Edmodo merupakan suatu layanan gratis yang memungkinkan dosen dapat menciptakan dan memelihara komunitas kelas mereka sendiri dengan aman [5]. Dengan demikian, melalui Edmono, proses pembelajaran akan tetap berjalan karena adanya komunikasi meskipun dilaksanakan jarak jauh.

Edmodo merupakan satu jejaring sosial berbentuk pembelajaran yang banyak membantu guru dan pelajar dalam proses pengajaran dan pembelajaran tanpa batasan menggunakan teknologi maklumat. Laman web Edmodo berfungsi sama seperti laman sosial yang lain seperti Facebook dan Twitter tetapi Edmodo lebih menekankan aspek pembelajaran secara maya. Penggunaan Edmodo adalah mudah dan percuma. Guru hanya perlu mendaftar sebagai guru dan mewujudkan sebuah kelas yang dikhaskan untuk pelajar bagi memudahkan komunikasi secara maya. Kemudian pelajar akan mendaftar sebagai pelajar dan memasuki ruangan yang telah dikhaskan untuk mereka dengan mendaftarkan kode ruangan yang telah diberi. Edmodo adalah platform media sosial yang sering digambarkan seperti facebook untuk sekolah dan dapat berfungsi lebih banyak lagi sesuai kebutuhan. Edmodo merupakan media yang menarik bagi guru dan peserta didik dengan elemen sosial yang menyerupai facebook [6]. Media yang menarik tentu 
Jurnal Ilmiah KONTEKSTUAL, Volume.2, No.01, Agustus 2020, pp. 8-14

akan membuat proses pembelajaran menjadi lebih bermakna dan tujuan pembelajaran dapat tercapai.

Edmodo pada dasarnya sama seperti pembelajaran yang berbasis web. Pembelajaran berbasis web dapat mempersiapkan mahasiswa untk memanfaatkan kemajuan teknologi dalam kehidupan sehari-hari [7]. Secara khusus, pembelajaran berbasis web yang memanfaatkan aplikasi Edmodo amat baik untuk diterapkan dan berkesan terhadap pelajar karena mereka mampu membina pengetahuan baru dan bermanfaat kepada diri sendiri. Indikator-indikator yang akan digunakan dalam penggunaan aplikasi Edmodo yaitu, (1) mengunduh bahan ajar, (2) merumuskan pertanyaan, (3) mengunggah hasil pekerjaan ke dalam Edmodo, (4) memberikan tanggapan pada fitur polling, (5) mengerjakan soal yang diberikan guru, dan (6) mengumpulkan tugas tepat pada waktunya [8].

Dengan penglibatan pelajar dalam laman sosial berkenaan akan membuat pelajar terlibat secara aktif dan dapat membina ingatan jangka panjang tentang sesuatu konsep dengan mengaitkan pengetahuan yang baru diterima dengan pengetahuan yang ada untuk membina pengetahuan. Edmodo mempunyai beberapa manfaat yang diperoleh yaitu meningkatkan interaksi antara dosen dan mahasiswa, membentuk sebuah kelas online, menambah variasi belajar, mengubah sistem pembelajaran yang tradisional menuju ke pembelajaran yang interaktif [5]. Berdasarkan uraian di atas, penulis membuat penelitian dengan judul Efektivitas Edmodo terhadap Hasil Belajar Mahasiswa PGSD Universitas Nusa Cendana.

\section{METODOLOGI PENELITIAN}

Penelitian ini dilaksanakan dengan penelitian eksperimen semu untuk mengetahui tingkat efektivas edmodo dalam pembelajaran. Sampel dipilih menggunakan teknik purposive sampling dengan pertimbangan bahwa jumlah mahasiswa dan tingkat kemampuan mahasiswa di kelas eksperimen. Berdasarkan teknik tersebut terpilihlah semester IIH PGSD Universitas Nusa Cendana, tahun akademik 2019/2020. Penelitian ini dilaksanakan pada bulan Februari sampai dengan bulan Mei 2020. Desain yang digunakan pada penelitian ini adalah pretest-posttest control group design. Pretest dilakukan sebelum diberikan perlakuan untuk mendapatkan data kemampuan awal mahasiswa. Posttest dilakukan setelah diberikan perlakuan untuk mendapatkan data hasil belajar mahasiswa. Tes hasil belajar ini sebagai alat untuk mendapatkan hasil belajar kognitif siswa. Tes formatif digunakan untuk mengukir tingkat validitas, reliabilitas, daya beda, dan tingkat kesukaran soal. Tes yang digunakan merupakan data yang diperoleh dari uji coba skala terbatas.

Uji validitas butir soal dalam perangkat pembelajaran pretest dan posttest yang diujicobakan pada kelompok terbatas dalam penelitian ini menggunakan perhitungan validitas item/butir dengan rumus kolerasi product moment. Suatu alat evaluasi dikatakan reliabel jika hasilnya relatif tetap, tidak dipengaruhi oleh faktor waktu, situasi, dan kondisi. Untuk menentukan harga reabilitas tes digunakan uji reliabilitas Kuder Richardson (KR.20) [9]. Untuk melihat keefektifan edmodo, peneliti menggunakan dua uji. Keefektifan yang dimaksud adalah ketepatan tujuan pembelajaran yang berupa penguasaan kompetensi siswa dalam pembelajaran dengan menggunakan edmodo. Untuk menguji keefektifan edmodo, dilakukan uji t untuk mengetahui ada perbedaan nilai mahasiswa pretest dan posttest kelas ekperimen, serta uji N-gain untuk mengetahui adanya peningkatan hasil belajar siswa.

\section{HASIL DAN PEMBAHASAN}

\section{Hasil Penelitian}

Pembelajaran sebelumnya berlangsung seperti biasa di dalam kelas. Mahasiswa belajar materi yang disampaikan dosen atau materi yang disampaikan mahasiswa yang lain. Keadaan itu tiba-tiba berubah setelah datangnya pendemi virus covid-19 yang masuk ke indonesia. Masuknya virus tersebut memberikan dampak perubahan besar pada pembelajaran di kelas khususnya 
pembelajaran di kampus PGSD Undana. Setelah diumumkannya untuk Work From Home (WFH) dosen harus tetap melaksanakan tugasnya mengajar jarak jauh dengan mahasiswa. Keadaan ini membuat dosen berpikir cara yang tepat untuk melaksanakan pembelajaran jarak jauh kepada mahasiswa.

Salah satu alternatif pembelajaran jarak jauh yang digunakan yaitu pembelajaran dengan aplikasi edmodo. Salah satu bentuk pembelajaran alternatif yang dapat dilaksasnakan selama masa darurat Covid-19 adalah pembelajaran secara online [10]. Hal tersebut dilakukan karena sebelum WFH peneliti sebagai dosen telah mengajarkan pada mahasiswa cara menggunakan edmodo. Langkah tersebut menjadi pegangan awal dosen untuk menggunakan aplikasi edmodo selama WFH. Pembelajaran dengan aplikasi edmodo diterapkan pada matakuliah belajar pembelajaran. Matakuliah ini harus dikuasai mahasiswa PGSD sebagai dasar menjadi calon guru. Karena matakuliah ini membahas teori-teori pembelajaran dan memahami karakteristik peserta didik. Seorang calon guru harus memahami kedua hal tersebut sebagai modal dalam mengajar. Kegiatan penelitian di laksanakan bulan april-mei 2020. Kegiatan pembelajaran dilaksanakan dengan aplikasi edmodo untuk kelas eksperimen.

Validitas instrumen soal ulangan harian, dilakukan uji validitas instrumen. Hasil uji validitas terhadap 20 soal ulangan harian yang diujicobakan pada kelompok kecil (uji skala terbatas) pada 20 mahasiswa PGSD. Diketahui jumlah mahasiswa yang dijadikan sampel adalah sebanyak 20, maka $r$ tabelnya adalah 0,444 . Hasil perhitungan $r$ hitung menunjukan soal yang digunakan seluruhnya memiliki nilai $r$ hitung rata-rata sekitar 0,555 di atas 0,444 . Hal ini dapat disimpulkan bahwa semua soal valid dan dapat digunakan untuk penelitian. Reliabilitas instrumen soal ulangan harian, dilakukan uji Reliabilitas instrumen. Hasil uji reliabilitas terhadap 20 soal ulangan harian yang diujicobakan pada kelompok kecil (uji skala terbatas) pada 20 mahasiswa PGSD Universitas Nusa Cendana.

Tabel 1. Hasil Reliablitias Instrumen Soal Uji Skala Kecil

\begin{tabular}{cc}
\hline \multicolumn{2}{c}{ Tabel reliabilitas } \\
\hline Cronbach's Alpha & Jumlah Soal \\
0,847 & 20 \\
\hline
\end{tabular}

Berdasarkan hasil uji reliabilitas instrumen tes ulangan harian dengan Alpha Cronbach dengan perhitungan SPSS 21 diperoleh nilai $r_{\text {hitung }}\left(r_{11}\right)=0,847$ dikatakan bahwa instrumen soal memiliki reliabilitas sangat tinggi. Keefektifan edmodo yang dikembangkan dilakukan dengan uji t untuk mengetahui ada perbedaan pretest dan postest kelas ekperimen serta uji $\mathrm{N}$-gain untuk mengetahui peningkatan pretest-posttest kelas eksperimen. Agar data hasil penelitian obyektif, maka dilakukan pengujian prasyarat yaitu uji normalitas dan uji homogenitas untuk mengetahui apakah kedua sampel (kelompok eksperimen dan kelompok kontrol) yang dipilih berasal dari populasi yang sama atau tidak. Dalam penelitian ini, uji normalitas dan uji homogenitas dilakukan sekaligus bersama dengan data penelitian terhadap hasil nilai pretes dan posttest pada kedua kelas eksperimen

Setelah uji prasyarat, dapat dilakukan uji hipotesis untuk mengetahui kefektifan produk (perangkat pembelajaran dengan edmodo dengan uji perbedaan nilai pretest dan posttest menggunakan SPSS 21 seperti disajikan pada Tabel 2

Tabel 2. Hasil Uji-t Pretest Posttest

\begin{tabular}{lc}
\hline & Pretest Posttest \\
\hline F & 2,666 \\
Asymp. Sig. (2-tailed) &, 000 \\
\hline
\end{tabular}

Berdasarkan Tabel 2, terlihat bahwa nilai signifikansi 0,000 $<0,05$ maka Ho ditolak dan Ha diterima, artinya hipotesis yang menyatakan ada perbedaan antara pretest dan posttest diterima, yang berarti bahwa setelah diberi pembelajaran dengan edmodo, ternyata perolehan nilai posttest lebih tinggi dari pretest. Jadi disimpulkan bahwa ada perbedaan nilai pretest dan posttest di kelas ekperimen dengan menggunakan edmodo. Dalam hal ini nilai posttest lebih tinggi dari pretest. 
Keefektifan edmodo yang dikembangkan dapat dilihat dari perbandingan peningkatan hasil belajar tiap individu secara keseluruhan melalui perbandingan rata-rata peningkatan nilai pretest dan posttes antara kelas eksperimen menggunakan uji N-gain seperti Tabel 3.

Tabel 3. Perbandingan Rata-rata N-gain

\begin{tabular}{cccc}
\hline \multicolumn{4}{c}{ Kelompok Eksperimen } \\
\hline Skor Ideal & Pretest & Posttest & N-gain \\
\hline 100 & 57,60 & 77,39 & 0,491 \\
\hline
\end{tabular}

Berdasarkan Tabel 3. dapat dilihat bahwa N-gain kelompok eksperimen 0,491 berada pada rentang $0,30 \leq \mathrm{g} \leq 0,70$ menunjukan kriteria sedang. Dengan demikian dapat disimpulkan bahwa penggunaan edmodo secara keseluruhan efektif untuk meningkatkan hasil belajar mahasiswa pada mata kuliah belajar pembelajaran.

\section{Pembahasan}

Dalam matakuliah belajar pembelajaran selama pandemi covid 19 dilaksanakan dengan aplikasi edmodo. Edmodo adalah situs micro blogging yang dapat digunakan di dalam kelas maupun rumah. Edmodo juga dapat membantu guru yang tidak bisa mengajar di kelas dengan memberikan materi pembelajaran secara online. Dalam Edmodo, Dosen bisa memberikan tugas yang bisa ditentukan waktu pengumpulannya serta meng-upload materi belajar. Mahasiswa juga bisa berbagi pemikiran atau ide lewat postinnya di Edmodo atau jika disamakan dengan facebook, bisa dikatakan Update Status. Edmodo yang diterapkan dalam penelitian ini, dapat melatih peserta didik lebih siap dalam mengikuti proses pembelajaran, mengajak peserta didik berfikir serta berperan secara aktif dalaam proses pembelajaran berlangsung [11].

Setelah pembelajaran dilaksanakan dengan edmodo memberikan hasil bahwa edmodo memiliki pengaruh pada hasil belajar mahasiswa. Hal tersebut dibuktikan dengan pengitungan hasil belajar mahasiswa melalui pretest dan posttest pada mata kuliah belajar dan pembelajaran kelas $\mathrm{H}$. Dari hasil perhitungan uji efektivitas yang dilaksanakan menggunakan uji $\mathrm{T}$ dan uji $\mathrm{N}$ gain. Uji T untuk pembelajaran menggunakan edmodo pada matakuliah belajar pembelajaran mendapatkan hasil nilai signifikansi $0,000<0,05$ maka Ho ditolak dan Ha diterima, artinya hipotesis yang menyatakan ada perbedaan antara pretest dan posttest diterima, yang berarti bahwa setelah diberi pembelajaran dengan edmodo, ternyata perolehan nilai posttest lebih tinggi dari pretest. Jadi disimpulkan bahwa ada perbedaan nilai pretest dan posttest di kelas ekperimen dengan menggunakan edmodo. Dalam hal ini nilai posttest lebih tinggi dari pretest. Hal ini berarti setelah mendapat suatu tindakan maka hasil belajar bisa berubah karena hasil belajar merupakan hasil dari suatu interaksi tindak belajar dan tindak mengajar [12].

Oleh sebab itu mengetahui adanya peningkatan hasil belajar menggunakan uji N Gain. Hasil $\mathrm{N}$ Gain menunjukan bahwa kelompok eksperimen 0,491 berada pada rentang $0,30 \leq \mathrm{g} \leq 0,70$ menunjukan kriteria sedang. Dengan demikian dapat disimpulkan bahwa penggunaan edmodo secara keseluruhan efektif untuk meningkatkan hasil belajar mahasiswa pada mata kuliah belajar pembelajaran. Pembelajaran yang telah dilaksanakan menggunakan edmodo memberikan dampak positif. Hasil belajar mahasiswa berubah saat pembelajaran jarak jauh menggunakan edmodo. Hasil belajar siswa adalah kemampuan yang diperoleh anak setelah melalui kegiatan belajar [13]. Hasil belajar merupakan hasil dari suatu interaksi tindak belajar dan tindak mengajar. Dari sisi guru, tindak mengajar diakhiri dengan kegiatan penilaian hasil belajar. Dari sisi peserta didik, hasil belajar merupakan berakhirnya panggal dan puncak proses belajar. Hasil belajar tersebut dapat dibedakan menjadi dua yaitu : (a) dampak pembelajaran (prestasi), dan (b) dampak pengiring (hasil). Dampak pembelajaran adalah hasil yang dapat diukur dalam setiap pelajaran (pada umumnya menyangkut domain kognitif), seperti tertuang dalam angka rapor dan angka dalam ijazah. Dampak pengiring adalah terapan pengetahuan dan kemampuan dibidang lain yang merupakan suatu transfer belajar (transfer of learning). 


\section{SIMPULAN}

Berdasarkan kajian teori dan analisis hasil penelitian yang telah dikemukakan pada bab sebelumnya, maka dapat disimpulkan sebagai berikut. Terdapat perbedaan hasil belajar pada pembelajaran menggunakan edmodo untuk mahasiswa PGSD Universitas Nusa Cendana nilai signifikansi uji T 0,000>0,005 yang berarti Ho ditolak dan Ha diterima. Hal ini berarti ada perbedaan antara pretest dan posttest, Peningkatan hasil belajar mata kuliah belajar pembelajaran pada pembelajaran menggunakan edmodo untuk mahasiswa PGSD Universitas Nusa Cendana dengan nilai $\mathrm{n}$-gain pada kelas eksperimen mencapai 0,65 yang berarti berada pada $0,70>\mathrm{g}>$ 0,30 kriteria sedang.

Sesuai dengan kesimpulan hasil penelitian, maka peneliti memberikan saran-saran sebagai berikut. Penerapan edmodo untuk meningkatkan hasil belajar mahasiswa ini dapat dijadikan salah satu alternatif model pembelajaran inovatif bagi dosen di masa pandemi covid 19, dosen wajib menggunakan pendekatan pembelajaran yang inovatif untuk meningkatkan hasil belajar mahasiswa.

\section{REFERENCES}

[1] Lestari, Sudarsri, "Peran Teknologi Dalam Pendidikan Di Era Globalisasi," Jurnal Edureligia, vol. 2, no. 2, pp. 91-100, 2018. [Online]. Available: https://ejournal.unuja.ac.id/index.php/edureligia/article/view/459

[2] Triputra, DR \& Kurniawan, PY, "Implementasi Media Pembelajaran Vlog Materi Dakwah Pada Mahasiswa Berdasarkan Aspek Keterampilan Berbahasa," Jurnal Ilmiah Kontekstual, vol.1, no. $1, \quad$ pp. 18-25, 2019, [Online]. Available: http://jurnal.umus.ac.id/index.php/kontekstual/article/view/54

[3] Rulviana, Vivi, "Implementasi Media Edmodo dalam Mata Kuliah Pengembangan Kurikulum Sekolah Dasar," Jurnal Refeksi Edukatika, vol. 8. no. 2, pp. 205-208 , 2018, [Online]. Available: https://jurnal.umk.ac.id/index.php/RE/article/view/2361

[4] Nurpratiwiningsih, L \& Prasetiyoko, DT, "Development of Education Games Map Material as Learning Media for Elementary School Students," Journal of Primary Education, vol.8, no. 3, pp. 249-257, [Online]. Available: https://journal.unnes.ac.id/sju/index.php/jpe/article/view/26251

[5] Dharmawati, "Penggunaan Media e-Learning Berbasis Edmodo Dalam Pembelajaran English for Business," QUERY: Jurnal Sistem Informasi, vol. 01, no. 01, pp. 43-46, 2017, [Online]. Available: http://jurnal.uinsu.ac.id/index.php/query/article/view/640/463

[6] Gatot, Priowijanto, "Materi Simulasi Digital," 2013, Seamolec, Jakarta.

[7] Mumpuni, A \& Nurpratiwiningsih, L, "The Development of a Web-Based Learning to Improve of a Creative Writing Ability of PGSD Students," Jurnal Cakrawala Pendidikan, vol. 37, no. 2, pp. 321-332, 2018, [Online]. Available: https://journal.uny.ac.id/index.php/cp/article/view/20009

[8] Putri, dkk, "Penggunaan Media Pembelajaran Edmodo Untuk Meningkatkan Aktivitas dan Hasil Belajar Siswa Kelas X Pemasaran Di Smk Negeri 1 Jember Tahun Ajaran 2016/2017," Jurnal Ilmiah Ilmu Pendidikan, Ilmu Ekonomi, dan Ilmu Sosial, vol. 11, no.1, pp. 108-114 2017, [Online]. Available: https://jurnal.unej.ac.id/index.php/JPE/article/view/6455

[9] Arikunto, S, “Dasar-Dasar Evaluasi Pendidikan,” 2012, Bumi Aksara, Jakarta

[10] Firman, F \& Rahman, SR, "Pembelajaran Online di Tengah Covid Pandemi 19," Indonesian Journal of Educational Science (IJES), vol. 2, no. 2, pp. 81-89, 2020, [Online]. Available: https://ojs.unsulbar.ac.id/index.php/ijes/article/view/659

[11] Rachmawati, dkk, "Pengaruh Media Edmodo Terhadap Hasil Belajar Peserta Didik Pada Mata Pelajaran Ekonomi Di SMA Negeri 1 Indralaya Utara," Jurnal Profit, vol. 2, no 2, pp. 186-193, 2015, [Online]. Available: https://core.ac.uk/download/pdf/267824880.pdf 
[12] Arifin, Zainal, "Penelitian Pendidikan Metode dan Paradigma Baru," 2012, Remaja Rosda Karya, Bandung

[13] Susanto, Ahmad, "Teori Belajar dan Pembelajaran di Sekolah Dasar," 2013, Kencana Prenada Media Group, Jakarta. 